\title{
Legislative Update: October 2001
}

\author{
Allison Weber Shuren, NP, JD* and Stacy Harbison, BS\#

\section{REVISION TO NURSE ANESTHETIST RULE} \\ claims that its monetary profits are far less than indicated \\ by Senator Lott.
}

The Bush Administration modified the Final Rule as published in the Federal Register in January 2001 removing the physician supervision requirement from the delivery of health care services provided by certified registered nurse anesthetists (CRNAs). The American Society of Anesthesiologists, as well as ASIPP, opposed the January Final Rule on this subject as offered by the Clinton White House and worked diligently to urge the new Administration to reconsider the rule. The Bush White House claims that additional review is needed and has offered an alternative proposal allowing Governors in concert with their state Boards of Medicine and Nursing to determine whether the physician supervision requirement is appropriate for their state. If not, then the state may obtain a waiver exemption from the requirement. The revised rule was published in July and comments were due September 4.

\section{CPT CODES}

Earlier this summer, Senate Minority Leader Trent Lott (R-MS) contacted the Department of Health and Human Services inquiring as to the efforts of CMS in updating codes, which are currently prepared by the American Medical Association (AMA). The letter asserts that the AMA has been granted a monopoly on these current procedural terminology (CPT) codes, which limits competition and which allows the organization to reap in millions of dollars in profit. According to the August 13 edition of the Health Care Daily Report, AMA contacted them by letter stating that their CPT codes have been tested and proven and that replacing them would undoubtedly come at large cost to the federal government. In addition, the AMA

From Arent Fox Klintner Plotkin \& Khan, PLLC, Washington, D.C. *Ms. Shuren is an attorney at Arent Fox and Counsel for American Society of Interventional Pain Physicians. "Ms. Harbison is a Government Relations Assistant. Address correspondence: Allison Weber Shuren, JD, 1050 Connecticut Avenue NW, Washington, D.C. 20036. Email: ShurenA@arentfox.com
Although Lott requested a response from CMS by August 20 , no response was available at the time of publication.

\section{MEDICARE GIVEBACKS}

CMS Administrator, Tom Scully, relayed during a managed care conference in May that a Medicare giveback bill is unlikely this session of Congress. The Chairman and the Ranking Minority Member of the Senate Finance Committee are from rural states and may place a high priority on aiding providers in those areas. Senate Finance Chairman Max Baucus represents the state of Montana, while the Ranking Minority Member, Charles Grassley, is from Iowa, but aside from possible rural providers, Scully does not foresee additional givebacks unless a broad Medicare reform bill is introduced addressing prescription drug coverage.

Senator Bob Graham (D-FL) has introduced a Medicare prescription drug coverage bill, and Senator Max Baucus (D-MT) is reported to be drafting legislation as well. The Senate Finance Committee hopes to review Medicare legislation following the August recess.

\section{EFFORTS TO STRENGTHEN THE MEDICARE PROGRAM}

In June, the Health and Human Services Secretary, Tommy Thompson, announced efforts being taken by the Center for Medicare and Medicaid Services (CMS) to improve, modernize, and strengthen the Medicare program. Those efforts include a name change; better education of beneficiaries; and improved response time from the agency.

Building upon these goals, in July, the President delivered eight additional broad reform principles for the Medicare program. They are:

- Provide beneficiaries with the option of a subsidized prescription drug benefit. 
Improve coverage for preventive care and serious illnesses.

- Provide an option for beneficiaries to maintain the traditional program.

- Provide better insurance options similar to the Federal Employees Health Benefit Plan.

- Strengthen the long term financial stability of the program.

- Improve management of the program.

- Update regulations and administrative procedures and reduce fraud and abuse.

- Encourage high quality health care for all beneficiaries.

The AARP has expressed strong support for the integration of prescription drug coverage, yet a number of critics on Capitol Hill and the private sector have voiced concern about the President's proposal to institute a prescription drug discount card. Critics contend that the small savings achieved by such a measure will not bring sufficient relief to senior citizens struggling with the high cost of medicine. However, the President's proposal provides on a framework for Congress, leaving much detail to be determined by the legislators.

\section{PATIENTS BILL OF RIGHTS}

The Senate passed a patients bill of rights at the end of June, but passing a similar bill in the House proved difficult. Congressman Norwood (R-GA), one of the primary leaders on this issue, reached an eleventh hour agreement with the White House prior to the August recess ensuring a slim passage of H.R. 2563. Unlike the Senate bill, which included virtually no caps on liability, save for a \$5 million cap on punitive damages, the House bill includes a number of caps and is viewed by some as the better bill.

The bills are scheduled for conference committee where the differences between the two will be reconciled. The conference is expected to be contentious, where liability caps, the role of state laws, and restrictions on class action suits will be discussed further. The conference members are expected to be chosen shortly after the August recess and several names have been mentioned as possibilities for inclusion, such as Senators Kennedy and Edwards and Congressmen Thomas, Tauzin, Boehner and Norwood.

\section{HIPAA}

The Health Insurance Portability and Accountability Act (HIPAA), which became law in 1996, establishes a num- ber of privacy rules designed to better protect patient health care records by developing a process for the use of information technology and by implementing appropriate guidelines in using patient health information. The Bush Administration has stated its desire to modify the existing rules with some much needed changes. For example, controversy has surrounded the current language which requires that a pharmacist obtain the patients signature prior to releasing a prescription drug, thereby prohibiting friends or family from retrieving medicine on the patient's behalf. On August 6, a number of health care organizations sent a letter to HHS encouraging quick release of the modifications to give appropriate time for implementation. This letter was followed up by correspondence from the National Governor's Association to leaders on Capitol Hill highlighting the need for health care systems, private and public, to review the rules in their entirety for complete and accurate implementation.

Most covered entities have until April 14, 2003 to comply with the Privacy Rule, small health plans have an additional year to comply. There are two bills (Senate Bill 836 and House Bill 1975) pending before the 107th Congress, however, that would extend the Privacy Rule compliance dates until twenty-four months after all three regulations required by Administrative Simplification provision of HIPAA are issued in final form or October 16, 2004, whichever occurs later. In effect, these bills tie and delay the compliance date of the Privacy Rule to the publication of the final Security Standards which may be issued sometime late this summer/early autumn.

\section{COMBINING MEDICARE PARTS A \& B}

The House Commerce Subcommittee on Health reviewed the pros and cons of combining Parts A \& B of the Medicare program during a June 14 hearing. Part A, which is financed through the payroll tax, provides coverage for in-patient hospital care, while Part B, financed through a combination of general tax revenue and beneficiary premiums, provides coverage for a variety of out-patient services.

Republicans and the White House contend that combining Parts A \& B would streamline and modernize the program, while Democrats assert that it is simply an attempt to use any resulting surplus for other government programs. William Scanlon with the General Accounting Office testified at the hearing reminding Congressional Members that although combining the two parts may provide a clearer view of the program's financial integrity, that a special 
accounting system would have to be devised to accommodate for the fact that enrollment in Part B is voluntary. Therefore, beneficiaries choosing not to receive that additional coverage should receive subsidized premiums.

Marilyn Moon with the Urban Institute further added that increasing funding for Medicare administration is the best avenue for strengthening Medicare performance.

\section{SETTLEMENT WITH OHIO HOSPITALS AND HHS}

The Ohio Hospital Association (OHA) and the American Hospital Association (AHA) joined together to challenge the use of the False Claims Act (FCA) by the Department of Health and Human Services (HHS), claiming that HHS was abusing the FCA through inappropriate enforcement of billing rules for outpatient laboratory services under the Medicare program. The agreed upon settlement stated that hospitals would no longer be required to file thorough annual compliance reports with the Inspector General, but rather must certify that the hospital has complied with certain compliance provisions, including training and education for those who bill for outpatient laboratory services. In addition, they must verify that written policies have been created and implemented.

AHA views this settlement as a victory as it illustrates that hospitals have a recourse through the courts when they feel that have been unfairly reproached for alleged violations.

\section{CASE INVOLVING UNDERTREATMENT OF PAIN}

In June, a California jury awarded a family $\$ 1.5$ million for the under treatment of pain to their 85 year old relative dying of lung cancer. The physician, who had no pain management education in medical school or otherwise, attempted to treat the man with Demerol, but the patient continued to complain of excruciating pain, ranging in levels from 7 to 10 (on a scale of 10 ). The family is also hoping to obtain a court order requiring the physician to receive pain management training.

\section{NURSING SHORTAGE}

The nursing shortage is receiving a great deal of attention nationally and from Capitol Hill, as illustrated through the numerous Congressional hearings that have been held, as well as the various bills that have been introduced on the topic. The Congressional Research Service, which provides research support for Members of Congress, released a report stating that a nursing shortage will occur by the year 2010 if the issue is not addressed quickly by the government or private organizations. The General Accounting Office also issued a report in July stating that "[a] serious shortage of nurses is expected in the future as demographic pressures influence both demand and supply."(p. 2)

The American Medical Association weighed in on this issue as well when the House of Delegates released a report calling upon physicians, hospitals and nurses to combine their efforts in addressing and alleviating this problem, which could possibly curtail quality and access of patient care. The AMA cited excessive paperwork and other administrative responsibilities carried out by RNs as obstacles that keep nurses from providing the health care duties that they are trained and educated to perform.

\section{EMBRYONIC STEM CELL RESEARCH}

On August 9, President Bush delivered a speech to the nation stating that limited federal funding of embryonic stem cell research would be allowed. In his remarks, he stated, "As a result of private research, more than 60 genetically diverse stem cell lines already exist. They were created from embryos that have already been destroyed, and they have the ability to regenerate themselves indefinitely, creating ongoing opportunities for research. I have concluded that we should allow federal funds to be used for research on these existing stem cell lines, where the life and death decision has already been made.” In addition, the Bush Administration has established a President's council to monitor stem cell research and to keep the nation apprised of the successes and concerns that arise.

This stance modifies the policy put in place by the Clinton Administration, which allowed for broader use. Although the former Administration prevented the use of federal dollars for the creation of embryos for research, it would have allowed private companies to do so.

Despite this statement by President Bush, this highly contentious issue isn't likely to go away. In addition, there are differing opinions on Capitol Hill and as funding levels are determined for the upcoming fiscal year for health care research, this topic will undoubtedly rear its head again. 